\title{
Turkish Students' Metaphors about the European Union
}

\author{
Gürbüz Ocak \\ Assoc. Prof., Afyon Kocatepe University, Turkey, gocak@aku.edu.tr \\ İjlal Ocak \\ Assoc. Prof., Afyon Kocatepe University, Turkey, iocak@aku.edu.tr \\ Deniz Özpınar \\ Teacher, Ministry of Education,
}

The aim of this qualitative study was to examine and compare the metaphors of Primary School Secondary Level Students related to the European Union. A total of 399 Primary School Secondary Level students were involved in this study. In the form given to students for data collection, the students were asked to express their opinions about European Union. According to the data gathered, the metaphors of the participants were categorized into 8 groups. According to the analysis and the results of the study, the students tried to explain the EU with positive concepts such as development of future, democracy, freedom, success. However, they also produced negative metaphors like dead end, abyss, colonist, difficulty, utilitarian, blankness. This study used a phenomenological design. The data was collected through a semi-structured Interview Form. The data were analysed with content analysis.

Keywords: Metaphor, European Union, primary schools secondary part

\section{INTRODUCTION}

Over the past decades, metaphors have been used in education at all levels and in the other social domain. It is something particular about the intersection of the human mind and the physical universe in which we live that makes metaphors obvious, perhaps ineluctable, vehicle for carrying human meaning (Fernandez, 1971; Quine, 1963). In the simplest way, analogical reasoning includes the adoption of a familiar source or experience to serve as a base analog that is then mapped onto an unfamiliar target analog (Bougher, 2012). Studies at the intersection of neurobiology, linguistics, philosophy, and other fields (Lakoff, 2002 and Lakoff \& Johnson, 1999) reinforce what theorists across the fields of education, philosophy, anthropology, and linguistics have argued for many years: that making and remaking reality with our minds is the way human beings make sense of the world and that much of this sense making is accomplished through metaphor (Cook-Sather, 2003). In Aristotle's Rhetoric, he praises metaphors as generating new insights claiming that "it is from metaphors that we can best get hold of new ideas" (quoted in Drulak, 2004:7). It is argued 
that metaphor is not only a matter of language (rhetorics) but also of thinking (epistemology) and of social practice (ontology). As Lakoff (1993) shows, the epistemological function lays grounds for the ontological function of metaphors. Metaphors shape our thinking, through our thinking they shape our actions, and through our actions they shape our reality.

Metaphors are comparisons that show how two things that are not alike in most ways are similar in one important way. Metaphors are a way of describing something. Unlike similes that use the words "as" or "like" to make a comparison, metaphors state that something is something else. Metaphors in text can help to build meaningful relations between what students already know and what they are setting out to learn (Anderson, 2000). The known case is a source; the unknown case is a target. In order to reach the target some associations are made. A metaphor "consists of the projection of one schema (the source domain of the metaphor) onto another schema (the target domain of the metaphor) to which the meaning is conveyed" (Levin \& Wagner, 2006:237). In other words, the target is the domain to be explained, and the source is the domain through which the target is being explained or conveyed metaphorically (Armstrong, 2008). There are a lot of definitions of metaphor made in various disciplines such as science, education, literature, law etc... In most literature classes, it is taught that metaphors add interest and mystery to the writings. In the last years, researchers and teacher educators have shown considerable interest in metaphors as a means to better understand how teachers perceive their most basic views about schooling, teacher, life, children, curriculum, and teaching (Lakoff \& Johnson, 1980; Munby, 1986; Provenzo, McCloskey, Kottkamp, \& Cohn, 1989; Tobin, 1990; Miller, 2002; Grisham, 2000; Gillespie, 2005; Ocak \& Gündüz, 2006; Ocak, 2011).

The metaphor has long been an essential tool for meaning making in literature and humanities, as well as generative of scientific discoveries (Miller, East, Fitzgerald, Heston, $\&$ Veenstra, 2002). Teachers have, consciously or not, used metaphors as a teaching tool in attempts to enhance student understanding of complex abstract concepts. Palmer (1998) suggests that teachers can also use metaphors to guide their reflections upon their practice and to illuminate paths for constructive change. Metaphor is one of the effective cognitive ways that people use in order to infer and to learn new concepts. The activity of building relations between present knowledge and new knowledge is important in the students' learning process. There is a growing body of literature that supports the study and use of students' metaphorical images in understanding how they conceptualize their learning. The European Union has an important place on the country's agenda due to the negotiations that have been initiated in recent years, in the accession process of Turkey to the European Union. It is thought that the students are also affected from this agenda both positively and negatively. Students between the negative and positive opinions, constitute their own metaphors about the EU. The applications brought forward in the integration process affect them too.

They also show how these practices may impact their conceptions of Europe. There are various ways of conceptualizing the students' images of Europe. These mostly rely on the well-established dichotomy between positive and negative aspects of Europe Union, outlining two possible conceptions of Europe. However, some studies attempt to transcend this dichotomy by introducing conception of Europe Union to do the specific complexities of European integration justice. According to Drulák \& Königová (2007), metaphor researches can be rewarding in several respects. To start with, it reveals the metaphoric situation of apparently neutral terms that are used when describing Europe, and it shows 
how these metaphors influence thinking about Europe. Moreover, metaphors provide useful connections between very different discourses that rely on similar conceptual metaphors. Not only can they link separate areas of research, such as EU institutional reform and the Europeanisation of national administrations, but they can also connect scholarly discussions and political or popular discourse. Furthermore, metaphorical analyses can help identifying new conceptions of Europe which have not been assumed by analysts but are relevant for actors. Finally, it is difficult to lie about metaphors (Hulsse 2003; quoted in Drulák \& Königová 2007) since they reflect our internalized beliefs. If people are asked to use metaphors rather than standard terminology when assessing the EU, they are likely to reveal what they really think. By soliciting students' EU metaphors, the study investigated how students frame EU images and ideas. Therefore, the purpose of this study was to examine students' metaphors of EU in general and then compare them in specific.

\section{Purpose of the Study}

The primary purpose of this research was to explore the students' metaphors about the European Union in second stage of primary schools and then the second purpose was to examine connections between metaphors in terms of some variables. In this frame, general purposes the answers were sought to the following questions: (1) What are the metaphors about the European Union created by the secondary school students? (2) Under what sort of conceptional categories can these metaphors be analyzed? (3) How differently do the metaphors created by the students distribute in terms of their fathers' occupations? (4) How differently do the metaphors created by the students distribute in terms of their mothers' occupations? (When parents share something about their occupations, it is inevitable for students to affect from them. If parents share something about their occupations including EU, the children can be affected from them). (5) How differently do the metaphors created by the students distribute in terms of the number of siblings? (6) How differently do the metaphors created by the students distribute in terms of the frequency of periodicals/newspapers delivered to their houses? (7) How differently do the metaphors created by the students distribute in terms of the sources that the students have learned about European Union?

\section{METHOD}

\section{Participants}

This research included 350 students of secondary school in Afyonkarahisar and Antalya. Students were between 13 and 15 years old and their socioeconomic status were heterogeneously distributed (tradesman, civil servant, worker, etc.). These participants were chosen because they were the youngest participant group who could answer the questions.

\begin{tabular}{llllll}
\hline $\begin{array}{l}\text { The fathers' } \\
\text { students } \\
\text { occupations }\end{array}$ & $\begin{array}{l}\text { Civil Servant } \\
\text { Tradesman }\end{array}$ & 88 & Periodicals & $\begin{array}{l}\text { Every day } \\
\text { Once or twice a }\end{array}$ & 118 \\
& $\begin{array}{l}\text { Worker } \\
\text { Unemplyoment }\end{array}$ & 46 & & $\begin{array}{l}\text { week/Sometimes } \\
\text { Only at the weekends } \\
\text { Never }\end{array}$ & 41 \\
& & 23 & & Television & 265 \\
\hline The mothers' & Officer & 43 & Sources & Newspaper & 32 \\
of students & Business & 24 & & Internet & 4 \\
occupations & Worker & 4 & & From the elders & 23 \\
& Unemployed & 248 & & From the teachers & 7 \\
\hline
\end{tabular}




\section{Data Collection}

In this study, students were asked to complete the sentences which were "European Union is................ because..................." in order to find out the metaphors they have about the European Union. In order to carry out this activity, all applicants were handed out paper prepared before. Before the students write their metaphors, all the explanations were made about the metaphors. Especially, it was underlined that they resemble the European Union to something else and write the reason for that similarity. 15 minutes was allocated to the students for writing their metaphors. This duration was seen as sufficient because the metaphors that first come to the applicants' minds were wanted to be used. The sentences that the students transferred their metaphors "European Union is. because..................." were the main sources of data collection of this study. In addition to that the students were asked 4 open ended and 4 closed ended questions about their mothers' and fathers' occupations, number of siblings, the frequency of the periodicals/ newspapers delivered to their houses, whether they had internet connection at their houses, the frequency of using the internet and from which sources they heard about the European Union.

\section{Analyzing the Data}

To analyze the metaphors, the two authors rated students' responses. Interrater reliability was consistently at or above $90 \%$ across multiple protocols. The discrepancies were resolved through discussion for the metaphors that were rated differently. This study was employed a key model as described by Everston, Weade, Green, and Crawford (1985). Each single metaphor was taken (typed on a paper by itself) and its content was analyzed (Ball \& Smith, 1992). The metaphor topic (EU) was provided for the students. The content was analyzed for the metaphor which in essence is the figurative statement.

In the study 399 secondary school students were asked to create metaphors but out of this number 313 students could create metaphors that were valid. The rest 86 students' metaphors were excluded from the analyze. The analyzing of the metaphors created and the conclusions were done in the following stages: (1) Identifying stage (2) Eliminating and clarifying stage (3) Reorganizing and Re-collecting stage (4) Developing categories stage (5) Transferring the data to computers for quantitative data analyzing (Saban, Koçbeker and Saban, 2005).

\section{Stage 1: Identifying:}

The metaphors students created were identified as concepts like "Westernization", "Unity", "Future", "Telephone", "Dead end", "Problem", "Income", "Vacancy" etc. While analyzing the data the metaphors which were not like in the given examples were not identified and were excluded from the analyze.

\section{Stage 2: Eliminating and Clarifying:}

Each metaphor was set apart and analyzed in terms of their similarity and common characteristics. Thus by analyzing the metaphors the students created, the process of eliminating 86 paper was done according to four main criteria: (a) The paper that was only about the definitions or that did not have any metaphor sources, (b) the paper talking about a certain metaphor but did not have any reason for the metaphor, (c) the metaphors that could 
be classified under more than one category (d) illogical metaphors or the metaphors which did not have anything with the European Union(Saban, Koçbeker and Saban, 2005).

Stage 3: Developing Categories:

The metaphors created by the students were classified under 8 main categories according to their similarities and relevance. 34 metaphors were excluded since they did not stand for any group determined. The metaphors created by the students were codified in respect of the variables they displayed according to the list in the third stage. Those codes were classified under the main categories afterwards according to the characteristics of the metaphors. For instance, the metaphors under the category of "European Union as CommunicationInteraction" all evaluate the European Union as "Communication-Interaction" basically (for example; telephone, vehicle, helpful, ladybird, bee, privilege etc.)

Stage 4: Transferring the data to statistics program for quantitative data analyze:

After identifying 139 metaphors and classifying the metaphors under 8 main groups, all the data was transferred to statistics program: After this procedure, first of all the number of the students (f) and their percentage (\%) representing each metaphor and category were found out.

\section{FINDINGS}

The results are presented through the guiding research questions.

1. What are the metaphors about the European Union created by the primary school second stage students?

General Findings

When we look at the most created metaphors totally it is found to be; Nothing $(n=19$, $10.9 \%)$, Community of the countries $(n=17,9.8 \%)$, and the Unity $(n=12,6,9 \%)$. Students used 173 metaphors totally about the European Union. Out of those metaphors, 139 of them were classified under 8 main groups whereas 34 of them were excluded since they did not represent any categories. Only one student created $110(63.5 \%)$ metaphors out of 178 that the students created. On the other hand, out of 139 metaphors that were classified under the main groups only one student created $85(61.1 \%)$ of them.

\section{Under what sort of conceptional categories can these metaphors be analyzed?}

\section{Main Groups}

\subsection{European Union as a Constitution}

Under this category, there are 41 metaphors created in total. (Union/ Unity, Forming unity/ Unity of the countries/ Democratically Unity/ European Union/ Economical-Political Union/ Political Union/ Racial Union, Particular Countries Union/ National Union/ Religion Union/ Cultural Union/ Political Union, Community/ An Important Community/ National Communities/ Political and Informational Community/ Colonial Nationalities Community/ A Modern Community/ European Countries Community/ Community of Civilizations/ Modern-Civilized Community, Country, Nation/ Developed Countries, Civilizations, Continent / A Large Continent, Brotherhood, Civilizations/ Committee of Civilizations/ 3rd Crusade, Forest, Group, Human Rights Committee/ Foreign Language Center, Factory of Employment, the Existence of countries coming together at the same place, Order, Administration, Independence, the place directing the relations between the countries). As it 
is understood from these metaphors, European Union represents a formation, unity, union, community. The metaphors that are created in this group consist of the $31.8 \%$ of all metaphors (Table 1). These metaphors (unique construction, constitutional treaty, federation of nation) show similarity with the metaphors that Drulak $(2004,2005)$ obtained in his researches. EU institutional structure is a special kind of international structure. It is surrounded by transnational speech community of politicians, experts, civil servants, activists, businesspeople and journalists who speak about the EU to one another using a shared language of European integration. This shared language about the EU institutional order lays grounds for the analysis of EU structure by means of metaphors. In this respect, the EU is seen as a target domain which can be metaphorically bridged to several source domains (Drulak, 2004:16). Drulak (2004) argued that the common sense about the EU is based on the EU as motion, container and equilibrium.

\subsection{European Union as Future}

In this group there are 15 metaphors students made in total. (Future/ The future of Children/ The Future of Turkey/ Mirror of the Future/ The star of the Future, Contribution, Development/ Development/ the World of Development/ The Place of Development/ Development for our Country, Tree, Era/ Modernization, Way.) As it is understood from these metaphors, European Union is seen as a future. The metaphors that are created in this group consist of $11.6 \%$ of all metaphors (Table 1).

Table 1: Comparing the Groups in terms of Their Categories

\begin{tabular}{|c|c|c|c|c|c|c|c|}
\hline$Q N$ & MAIN GROUPS & $f$ & $\%$ & $Q N$ & MAIN GROUPS & $f$ & $\%$ \\
\hline 1 & Constitution & 41 & $\% 31,8$ & 5 & Self-seeking & 15 & $\% 11,6$ \\
\hline 2 & Future & 15 & $\% 11,6$ & 6 & Profit & 21 & $\% 16,3$ \\
\hline 3 & $\begin{array}{l}\text { Interaction- } \\
\text { Communication }\end{array}$ & 20 & $\% 15,5$ & 7 & Similarity & 6 & $\% 4,7$ \\
\hline 4 & Ambiguity & 4 & $\% 3,1$ & 8 & Ineffective & 7 & $\% 5,4$ \\
\hline
\end{tabular}

\subsection{European Union as Interaction-Communication}

In this group there are 20 metaphors that the students made. (Telephone, a vehicle, helpful, ladybird, bee, privilege, superiority, enlightenment, life style, negotiation, locomotive, medicine, solidarity, branches of a tree, interaction, magnet, history, television, basic, the head of Europe) As it is also understood from these metaphors, the European Union is seen as a source of Interaction-Communication. The metaphors that are created in this group consist of $15.5 \%$ of all metaphors (Table 1 ).

\subsection{European Union as Ambiguity}

In this group there are four metaphors that the students used. (Dead end, a door which cannot be entered through, dead well, closed book) As it is understood from these metaphors, European Union is considered as an ambiguity. The metaphors that were created in this group consist of $3.1 \%$ of all metaphors (Table 1). The lack of information about the EU might have been effective for the students to see the EU as an ambiguity. Thus, according to European Commission (2006), The EU citizens call for more information and communication about EU enlargement in order to assess better the benefits and challenges of this process, in the context of a clear political project for Europe. The results of this survey also point out that people living in the European Union primarily expect national governments and the media to provide them with such information. Chaban, Bain \& Stats 
(2007) argue providing evidence that the public discourses of the EU's external counterparts are inclined to interpret its evolution in somewhat different terms while the EU sees itself as a peaceful and integrationist entity that states taking humanitarian values to its center and automatically expects a "corresponding international appreciation". Certainly in case of a complex process like the enlargement of the European Union, there are numerous parameters which shape citizens' attitudes towards this issue. This survey has shown that lack of information is a factor strongly perceived by EU citizens and it affects their attitudes towards future enlargement (European Commission, 2006).

\subsection{European Union as Self-seeking}

In this group there are 15 metaphors that the students used in total (Colonial/ Colonialism, Detaining, Octopus, Self-seeking, Considering itself very clever, Thorn, Putting Turkey off, Inspector, Normative, Command machine, Countries taking advantage of us, Constitution, Difficulty, Problem, Land, Border.). As it is understood from these metaphors, European Union is considered as a constitution which takes advantage of Turkey. The metaphors that are created in this group consists of $11.6 \%$ of all metaphors (Table 1).

\subsection{European Union as a Profit/ Advantage}

In this group there are 21 metaphors that the students used in total (Profit, Advantage, Fortune, Responsibility, Opportunity, Facility, Power, Drugstore, Developing the Country, Democracy, Modern National Style, Economical Value, Sun, Aim, Success, Freedom, Principal, Teacher, Job, and Advantage for our country, Flower, Beautiful, Freedom, Support, Necessity, Importance). As it is understood from these metaphors, European Union is considered as a constitution which is an advantage for Turkey. The metaphors that are created in this group consist of $16.3 \%$ of all metaphors (Table 1).

\subsection{European Union as Resemblance}

In this group there are 7 metaphors that the students used (Westernization, Emulation, Trying to assimilate, Captivity, A process of changes / A change in our country, Tournament). As it is understood from these metaphors, European Union is considered as adapting our country to the foreign countries. The metaphors that are created in this group consist of $4.7 \%$ of all metaphors (Table 1 ).

\subsection{Ineffective European Union}

In this group there are 7 metaphors that the students used (Nothing, Emptiness,

Nonsense, Unimportant, A Vain Idea, Dream). As it is understood from these metaphors, European Union is considered as ineffective and unnecessary. The metaphors that are created in this group consist of $5.4 \%$ of all metaphors (Table 1).

\subsection{The Metaphors Excluded}

Totally 34 metaphors were eliminated in the study since they did not represent any category. (Good, regime, so-so, torture, Christian, dead machine, our fortune, everything, fox, mistake, father, bad, bloodsucker, cannibal, home, the government of the country, peace invitation, water, source of income, unbeliever country, city, region, enemy, supervision, head louse, clean country, an important idea, insect, peace contract, apple, brain, ball, genius, clock, the king of the world) The ratio of these metaphors to all the metaphors is $21.3 \%$. These 8 categories (Table 1) show the diversity that students possess about their 
view of EU. Common metaphors that appear in our findings and across studies are unique construction, constitutional treaty, federation of nation (Drulak, 2005).

According to the Table 1, most produced metaphor that the students consider the European Union as a constitution is used by $41(31,8 \%)$. It is notable that in a research comparing two British newspapers -namely Guardian and Sun- about their use of metaphors for EU there is also a code as "EU constitution + building" (Kimmel, 2009). It is followed by 21 students $(16,3 \%)$ which see the European Union as an advantage. In the group consisting of the ones seeing European as an interaction 20 metaphors (15.5\%) are classified. Kimmel also coded such a title -force dynamic interaction- in the research mentioned above (Kimmel, 2009). Whereas the group that considers the European Union as self-seeking and as a future formed equal numbers of metaphors by $15(11.6 \%)$. Following these, those seeing European Union as ineffective consists of $7(5.4 \%)$ metaphors, seeing European Union as a resemblance consist of $6(4.7 \%)$ metaphors and the seeing European Union as an ambiguity consist of $4(3.1 \%)$ metaphors (Table 1$)$.

The most comprehensive account of metaphors deployed in the discourse about the EU is provided by Musolff $(2000,2004$, 2006) who has researched Western cultural models relating to metaphors encountered in British and German press. He has compiled two corpora, Eurometa I and Eurometa II, which cover the period from 1989 -2001, and analysed metaphorical expressions regarding European politics. On the basis of available data, Musolff has identified several source domains, the following four being the main ones to conceptualize the EU-love-marriage-family, path-movement-journey, life-body-health and building-housing source domains (Durovic, 2009). Sabate Dalmau (2005) has compared Musolffs' corpus, Eurometa II, which comprises Love-marriage-family metaphors to the one she has compiled, Eurometa III, made up of examples of the Catalan public discourse. Her analysis has confirmed that the Catalan press -similar to the British press- shares the conceptual metaphor Europe is a marriage as well as corresponding domains, such as Love, kinship, the relationship, separation, adultery.

\section{How differently do the metaphors created by the students distribute in terms of their fathers' occupations?}

In the Table II below, the relation between the first variable -occupation of the father- and the metaphors the students created is shown. According to the Table 2, it is seen that the students whose fathers are officers used the metaphor number 1 most $(n=28 ; 31.8 \%)$ while they used the metaphors number $2(n=5 ; 5.7 \%)$ and number $4(n=5 ; 5.7 \%)$ least. The students whose fathers are workers used the metaphor number 1 most $(\mathrm{n}=14 ; 30.4 \%)$. There is no student whose father is a worker using the metaphor number $4(n=0)$. The students whose fathers have independent business used the metaphor number 1 most $(n=52 ; 33.3 \%)$ while those students used the metaphors number $4(\mathrm{n}=1 ; 0.6 \%)$ and number $7(\mathrm{n}=1 ; 0.6 \%)$ least. The students whose fathers do not work used the metaphor number $1(n=11 ; 47.8 \%)$ most as well. On the other hand there are no students whose fathers do not work using the metaphors number 4 and $8(n=0)$. When we look at the table in general, students in each group in terms of their fathers' job used the metaphor number 1 most $(\mathrm{n}=105 ; 33.5 \%)$. 
Table 2: Comparing the Metaphors in terms of Fathers' Occupations

\begin{tabular}{|c|c|c|c|c|c|c|c|}
\hline $\begin{array}{l}\text { Father's } \\
\text { occupation }\end{array}$ & $\begin{array}{l}\text { Code of the } \\
\text { metaphor }\end{array}$ & $f$ & $\%$ & $\begin{array}{l}\text { Father's } \\
\text { occupation }\end{array}$ & $\begin{array}{l}\text { Code of the } \\
\text { metaphor }\end{array}$ & $f$ & $\%$ \\
\hline \multirow{8}{*}{ Officer } & 1 & 28 & 31.8 & \multirow{8}{*}{ Business } & 1 & 52 & 33.3 \\
\hline & 2 & 5 & 5.7 & & 2 & 16 & 10.3 \\
\hline & 3 & 10 & 11.4 & & 3 & 10 & 6.4 \\
\hline & 4 & 5 & 5.7 & & 4 & 1 & 0.6 \\
\hline & 5 & 13 & 14.8 & & 5 & 20 & 12.8 \\
\hline & 6 & 12 & 13.6 & & 6 & 28 & 17.9 \\
\hline & 7 & 6 & 6.8 & & 7 & 1 & 0.6 \\
\hline & 8 & 9 & 10.2 & & 8 & 28 & 17.9 \\
\hline \multirow{8}{*}{ Worker } & 1 & 14 & 30.4 & \multirow{8}{*}{ Unemployed } & 1 & 11 & 47.8 \\
\hline & 2 & 6 & 13 & & 2 & 3 & 13 \\
\hline & 3 & 5 & 10.9 & & 3 & 1 & 4.3 \\
\hline & 4 & 0 & 0 & & 4 & 0 & 0 \\
\hline & 5 & 4 & 8.7 & & 5 & 5 & 21.7 \\
\hline & 6 & 8 & 17.4 & & 6 & 2 & 8.7 \\
\hline & 7 & 7 & 4.3 & & 7 & 1 & 4.3 \\
\hline & 8 & 7 & 15.2 & & 8 & 0 & 0 \\
\hline
\end{tabular}

4. How differently do the metaphors created by the students distribute in terms of their mothers' occupations?

In the Table 3 below, the relation between the second variable -mother's occupation- and the metaphors the students used are shown. According to the table, it is seen that the students whose mothers are officers used the metaphor number $6(n=12 ; 27.9 \%)$ most, while those students did not ever use the metaphor number $4(n=0)$. We could not obtain reliable data about the students' metaphors whose mothers were workers since there were so few of them. The students whose mothers were dealing with independent business created the metaphor number $8(\mathrm{n}=8 ; 11.1 \%)$ most, while none of those students used the metaphors number 4 and $5(\mathrm{n}=0, \mathrm{n}=0)$. The students whose mothers do not work and most of whom are housewives used the metaphor number $1(\mathrm{n}=88 ; 35.5 \%)$ most whereas those students used the metaphors number 4 and 7 least $(n=6 ; 2.4 \%)(n=6 ; 2.4 \%)$.

Table 3: Comparing the Metaphors in terms of Mothers' Occupations

\begin{tabular}{|c|c|c|c|c|c|c|c|}
\hline $\begin{array}{l}\text { Mothers' } \\
\text { occupation }\end{array}$ & $\begin{array}{l}\text { Code of the } \\
\text { metaphor }\end{array}$ & $f$ & $\%$ & $\begin{array}{l}\text { Mothers' } \\
\text { occupation }\end{array}$ & $\begin{array}{l}\text { Code of the } \\
\text { metaphor }\end{array}$ & $f$ & $\%$ \\
\hline \multirow{8}{*}{ Officer } & 1 & 9 & 20.9 & Business & 1 & 7 & 38.9 \\
\hline & 2 & 2 & 4.7 & & 2 & 2 & 11.1 \\
\hline & 3 & 7 & 16.3 & & 3 & 1 & 5.6 \\
\hline & 4 & 0 & 0 & & 4 & 0 & 0 \\
\hline & 5 & 5 & 11.6 & & 5 & 0 & 0 \\
\hline & 6 & 12 & 27.9 & & 6 & 5 & 27.8 \\
\hline & 7 & 3 & 7 & & 7 & 1 & 5.6 \\
\hline & 8 & 5 & 11.6 & & 8 & 8 & 11.1 \\
\hline \multirow{8}{*}{ Worker } & 1 & 1 & 25 & Unemployed & 1 & 88 & 35.5 \\
\hline & 2 & 1 & 25 & & 2 & 25 & 10.1 \\
\hline & 3 & 0 & 0 & & 3 & 18 & 7.3 \\
\hline & 4 & 0 & 0 & & 4 & 6 & 2.4 \\
\hline & 5 & 1 & 25 & & 5 & 36 & 14.5 \\
\hline & 6 & 1 & 25 & & 6 & 32 & 12.9 \\
\hline & 7 & 0 & 0 & & 7 & 6 & 2.4 \\
\hline & 8 & 0 & 0 & & 8 & 37 & 14.9 \\
\hline
\end{tabular}




\section{How differently do the metaphors created by the students distribute in terms of the number of siblings?}

In the Table 4 below, the relation between the third variable -number of the siblings- and the metaphors the students used is shown. According to the table the students who are the only child in the family used the metaphor number $1(n=20 ; 42.6 \%)$ most, whereas none of those students used the metaphor number $4(n=0)$. The students who have one sibling used the metaphor number $1(\mathrm{n}=44 ; 31.4 \%)$ most, while those students used the metaphor number 4 $(n=1 ; 0.7 \%)$ least. The students who have two siblings used the metaphor number $1(n=30$, $33 \%)$ most, while those students used the metaphor number $7(n=2 ; 2.2 \%)$ least. The students who have three siblings used the metaphor number $1(n=9 ; 37.5 \%)$ most, while none of those students used the metaphor number $4(\mathrm{n}=0)$. We could not obtain reliable data about the students' metaphors that have 4 and more siblings since there were so few of them.

Table 4: Comparing the Metaphors in terms of the Number of Siblings

\begin{tabular}{|c|c|c|c|c|c|c|c|c|}
\hline $\begin{array}{l}\text { Number of } \\
\text { siblings }\end{array}$ & $\begin{array}{l}\text { Code of the } \\
\text { metaphor }\end{array}$ & $f$ & $\%$ & $\begin{array}{l}\text { Number of } \\
\text { siblings }\end{array}$ & $\begin{array}{l}\text { Code of } \\
\text { metaphor }\end{array}$ & the & $f$ & $\%$ \\
\hline \multirow{8}{*}{1} & 1 & 20 & 42.6 & \multirow{8}{*}{4} & 1 & & 9 & 37.5 \\
\hline & 2 & 5 & 10.6 & & 2 & 2 & & 8.3 \\
\hline & 3 & 4 & 8.5 & & 3 & 4 & & 16.7 \\
\hline & 4 & 0 & 0 & & 4 & 0 & & 0 \\
\hline & 5 & 9 & 19.1 & & 5 & 1 & & 4.2 \\
\hline & 6 & 4 & 8.4 & & 6 & 5 & & 20.8 \\
\hline & 7 & 0 & 0 & & 7 & 1 & & 4.2 \\
\hline & 8 & 5 & 10.6 & & 8 & 2 & & 8.3 \\
\hline \multirow{8}{*}{2} & 1 & 44 & 31.4 & \multirow{8}{*}{$5+$ and } & 1 & & 2 & 18.2 \\
\hline & 2 & 12 & 8.6 & & 2 & 1 & & 9.1 \\
\hline & 3 & 12 & 8.6 & & 3 & 3 & & 27.3 \\
\hline & 4 & 1 & 0.7 & & 4 & 0 & & 0 \\
\hline & 5 & 17 & 12.1 & & 5 & 1 & & 9.1 \\
\hline & 6 & 26 & 18.6 & & 6 & 2 & & 18.2 \\
\hline & 7 & 7 & 5 & & 7 & 0 & & 0 \\
\hline & 8 & 21 & 15 & & 8 & 2 & & 18.2 \\
\hline \multirow{8}{*}{3} & 1 & 30 & 33 & & & & & \\
\hline & 2 & 10 & 11 & & & & & \\
\hline & 3 & 3 & 3.3 & & & & & \\
\hline & 4 & 5 & 5.5 & & & & & \\
\hline & 5 & 14 & 15.4 & & & & & \\
\hline & 6 & 13 & 14.3 & & & & & \\
\hline & 7 & 2 & 2.2 & & & & & \\
\hline & 8 & 14 & 15.4 & & & & & \\
\hline
\end{tabular}

Table 5: Comparing the Metaphors in terms of the Frequency of the Periodicals, Newspapers They Receive

\begin{tabular}{|c|c|c|c|c|c|c|c|c|}
\hline \multicolumn{2}{|c|}{ The newspaper } & \multicolumn{3}{|c|}{ Code of the } & The newspaper & \multicolumn{2}{|l|}{ Code of the } & \multirow[b]{2}{*}{$\%$} \\
\hline $\begin{array}{l}\text { delivered } \\
\text { their houses }\end{array}$ & to & metaphor & $f$ & $\%$ & $\begin{array}{l}\text { delivered to } \\
\text { their houses }\end{array}$ & metaphor & $f$ & \\
\hline \multirow{6}{*}{\multicolumn{2}{|c|}{ Every day }} & 1 & 31 & 26.3 & \multirow{6}{*}{$\begin{array}{l}\text { Once or twice } \\
\text { a week } \\
\text { Sometimes }\end{array}$} & 1 & 46 & 41.4 \\
\hline & & 2 & 10 & 8.5 & & 2 & 14 & 12.6 \\
\hline & & 3 & 6 & 5.1 & & 3 & 13 & 11.7 \\
\hline & & 4 & 3 & 2.5 & & 4 & 1 & 0.9 \\
\hline & & 5 & 20 & 16.9 & & 5 & 8 & 7.2 \\
\hline & & 6 & 20 & 16.9 & & 6 & 14 & 12.6 \\
\hline
\end{tabular}




\begin{tabular}{|c|c|c|c|c|c|c|c|}
\hline & 7 & 6 & \multicolumn{2}{|l|}{5.1} & 7 & 4 & 3.6 \\
\hline & 8 & 22 & \multicolumn{2}{|l|}{18.6} & 8 & 11 & 9.9 \\
\hline \multirow{8}{*}{$\begin{array}{l}\text { Only at } \\
\text { weekends }\end{array}$} & 1 & 10 & \multicolumn{2}{|l|}{24.4} & 1 & 18 & 41.9 \\
\hline & 2 & 5 & \multicolumn{2}{|l|}{12.2} & 2 & 1 & 2.3 \\
\hline & 3 & 4 & 9.8 & \multirow[t]{6}{*}{ Never } & 3 & 3 & 7 \\
\hline & 4 & 1 & 2.4 & & 4 & 1 & 2.3 \\
\hline & 5 & 8 & 19.5 & & 5 & 6 & 14 \\
\hline & 6 & 9 & 22 & & 6 & 7 & 16.3 \\
\hline & 7 & 0 & 0 & & 7 & 0 & 0 \\
\hline & 8 & 4 & 9.8 & & 8 & 7 & 16.3 \\
\hline
\end{tabular}

6. How differently do the metaphors created by the students distribute in terms of the frequency of periodicals/newspapers delivered to their houses?

In the Table 5 below, the relation between the fourth variable-the frequency of newspapers or periodicals- and the metaphors the students used is shown. According to the table, the students whose houses are delivered newspapers daily used the metaphor number $1(n=31$; $26.3 \%)$ most, while those students used the metaphor number $4(n=3 ; 2.5 \%)$ least. On the other hand, the students whose houses were delivered newspapers only at the weekends used the metaphor number $1(n=10 ; 24.4 \%)$ most, while none of those students used the metaphor number $7(\mathrm{n}=0)$. The students whose houses are delivered newspapers sometimes or once or twice a week used the metaphor number $1(n=30 ; 33 \%)$ most as well, on the other hand those students used the metaphor number $4(n=1 ; 0.9 \%)$ least. The students whose houses are never delivered any newspaper used the metaphor number $1(n=18 ; 41.9 \%)$ most, while none of those students used the metaphor number $7(n=0)$. When we look at the table in general, it is seen that the frequency of the newspapers delivered does not have an effect on the metaphors preferred most. The metaphor number 1 was used most in all groups $(n=105$; $33.5 \%$ ). It is also seen that the students whose houses are sometimes delivered newspapers and never delivered newspapers did not ever use the metaphor number 4.

7. How differently do the metaphors created by the students distribute in terms of the sources that the students have learned about European Union?

In the Table 6 below, the relation between the seventh variable -where they heard the European Union from- and the metaphors the students used is shown. According to the table, the source from which the European Union is heard most is the television $(n=265$; $84.7 \%$ ). The students who learned about the European Union from the television used the metaphor number $1(n=92 ; 34.7 \%)$ most. The students who heard the European Union from their elders used the metaphor number $1(n=8 ; 34.8 \%)$ most; while those students did not ever use the metaphors number 7 and number $4(n=0, n=0)$.

Table 6: Comparing the metaphors according to where they heard about the European Union from

\begin{tabular}{llllllll}
\hline $\begin{array}{l}\text { Where they } \\
\text { heard the EU } \\
\text { Union from }\end{array}$ & $\begin{array}{l}\text { Code of } \\
\text { the } \\
\text { metaphor }\end{array}$ & $f$ & $\%$ & $\begin{array}{l}\text { Where they } \\
\text { heard the EU } \\
\text { from }\end{array}$ & $\begin{array}{l}\text { Code of the } \\
\text { metaphor }\end{array}$ & $f$ \\
\hline & 1 & 92 & 34.7 & & 1 & 8 & 34.8 \\
& 2 & 26 & 9.8 & & 2 & 3 & 13 \\
Television & 3 & 23 & 8.7 & & 3 & 2 & 8.7 \\
& 4 & 5 & 1.9 & From the elders & 4 & 5 & 0 \\
& 5 & 34 & 12.8 & & 5 & 3 & 13 \\
& 6 & 41 & 15.5 & & 7 & 5 & 21.7 \\
\end{tabular}




\begin{tabular}{|c|c|c|c|c|c|c|c|c|}
\hline & 8 & 35 & 13.2 & & & 8 & 2 & 8.7 \\
\hline \multirow{8}{*}{ Newspaper } & 1 & 3 & 21.4 & & & 1 & 2 & 28.6 \\
\hline & 2 & 0 & 0 & & & 2 & 0 & 0 \\
\hline & 3 & 1 & 7.1 & From & the & 3 & 0 & 0 \\
\hline & 4 & 0 & 0 & teachers & & 4 & 1 & 14.3 \\
\hline & 5 & 2 & 14.3 & & & 5 & 2 & 28.6 \\
\hline & 6 & 3 & 21.4 & & & 6 & 0 & 0 \\
\hline & 7 & 1 & 7.1 & & & 7 & 0 & 0 \\
\hline & 8 & 4 & 28.6 & & & 8 & 2 & 28.6 \\
\hline \multirow{8}{*}{ Internet } & 1 & 0 & 0 & & & & & \\
\hline & 2 & 1 & 25 & & & & & \\
\hline & 3 & 0 & 0 & & & & & \\
\hline & 4 & 0 & 0 & & & & & \\
\hline & 5 & 1 & 25 & & & & & \\
\hline & 6 & 1 & 25 & & & & & \\
\hline & 7 & 0 & 0 & & & & & \\
\hline & 8 & 1 & 25 & & & & & \\
\hline
\end{tabular}

\section{CONCLUSION, DISCUSSION AND SUGGESTIONS}

In the study conducted, the analysis of the EU concept according to student thoughts has been presented from the data obtained from the metaphors that primary school students use to evaluate the European Union.

The students tried to express that they see the EU as an institution, as a community of states, a community of civilizations.

The students tried to explain the EU more with positive concepts like future, development, democracy, freedom, success. However, they produced negative metaphors like dead end, abyss, colonist, difficulty, utilitarian, blankness.

A similar study conducted in Northern Ireland shows that knowledge of the EU, its policies and institutions is low in Northern Ireland, and that there are significant differences across socioeconomic, gender and educational groups. However, there is some evidence that knowledge levels are higher in areas of immediate relevance, for example travel and voting, that is, in relation to citizenship rights type issues. Overall, attitudes towards the EU are relatively favourable and are becoming more positive over time. Supporting this trend, it is noteworthy that the vast majority of the respondents (86\%) agree that 'children in Northern Ireland should be taught about the EU and how it works' and only $2 \%$ disagree with this statement (O'Connor and McGowan, 2003).

According to the classification made of metaphors produced by the students they tried to define the EU as follows: 43 of the students as an institution, 15 of the students as future, 20 of the students as interaction-communication, 4 of the students as indistinctness, 17 of the students as utilitarian, 26 of the students as benefit, 7 of the students as likeness, 7 of the students as ineffective and metaphors by 34 of the students cannot be included to any group; with a sum of 173 metaphors.

However, perceptions vary quite markedly between respondents in the EU15 countries and those in the NMS12. The latter give pride of place to the free movement of people, goods and services within the European Union (62\%), followed by peace (54\%), whereas the order is reversed in the EU15 countries (48\% and 53\%). While respondents in the EU15 countries then mentioned the euro (30\%), those in the NMS12 countries preferred the economic power 
of the EU (25\%) and ERASMUS programmes (24\% versus $23 \%$ for the euro) (Standard Eurobarometer 77, 2012).

We could not obtain reliable data from the students' metaphors who heard the European Union from the newspapers; internet or their teachers since the number of those students were very few. The metaphors that the students of primary school second stage do not have much difference in terms of the variables determined before.

It is understood that there are not big differences in terms of the variables in the percentages of the main groups who created metaphors about the European Union.

The vast majority of Britons (82\%) said that they knew either little $(68 \%)$ or nothing $(14 \%)$ about the EU's institutions and policies. Men felt more knowledgeable about EU matters ( $25 \%$ vs. $11 \%$ of women said they knew either a great deal or quite a lot). The youngest respondents (15-24 years) were the least likely of all socio-demographic groups to feel informed (6\%). The British public was split in its attitudes toward the EU: $42 \%$ had a quite positive or very positive image of the EU, while almost as many respondents had a quite - or very negative view (39\%). 13\% took a neutral stance (neither positive nor negative) and $6 \%$ had no opinion on this matter. A positive perception of the EU was well above average among the youngest respondents (aged 15-24: 63\%), full-time students (67\%) and those with the highest level of education (59\%), as well as among respondents from metropolitan areas $(52 \%)$. On the other hand, manual workers (53\%), British citizens older than 54 $(48 \%)$, rural residents $(45 \%)$, those with the lowest level of education $(48 \%)$ and men $(45 \%)$ were particularly likely to have a negative image of the EU (Flash Eurobarometer, 2011).

In addition to students' perspectives, some supporters' and opponents' of Turkey's EU membership perspectives can be differently faced. For supporters and opponents of Turkey's EU membership, arguments come from two different sets of talking points. While Turkey and its supporters, such as the United States, argue in support of Turkey's role as an important regional energy and foreign policy actor, many in Europe express concern regarding Turkey's political, economic, social, and religious orientation. Turkey and its supporters argue that Turkey, through the EU plan to build the Nabucco gas pipeline in part through Turkey, will play an even more important energy role and could play an important role with respect to Iraq, Iran, Russia, and the Black Sea region. These advocates sometimes seem miffed that the EU does not appear to appreciate that role or place a greater importance on those issues when considering Turkey. Europeans, on the other hand, point out that while energy security and foreign policy are important elements in the operations of the EU, those issues comprise only two or three of 35 chapters in the acquis, and Turkey must come into compliance with the requirements of the entire acquis (Morelli and Migdalovitz, 2009).

The views of the students and their parents can be obtained about the problems of the education in the process of entering the European Union; after identifying the changes and standard arrangements this information can be transferred to the teacher trainee candidates in the Education Department of the universities.

Our future can be enlightened about the European Union both in our country and in the other European Union countries and by comparing the views of the students and by identifying expectancies, differences and the present situation analysis.

Among the results obtained from the study conducted, there are negative metaphors stemming from insufficient introduction of the European Union to the students from Turkey. 


\section{REFERENCES}

Anderson, T. (2000) Metaphors in Teaching. Retrieved January 14, 2010, from http://lrs.ed.uiuc.edu/students/fretzin/EPL11q5Metaphors.htm

Armstrong, S. L. (2008). 'Using Metaphor Analysis to Uncover Learners' Conceptualizations of Academic Literacies in Postsecondary Developmental Contexts, The International journal of learning, 15(9), 211-218 (online http://www.Learning-Journal.com).

Ball, M. S. \& Smith, G. W. H. (1992).Analyzing Visual Data. Newbury Park, CA: Sage.

Bougher, L. D. (2012). The case for metaphor in political reasoning and cognition. Political Psychology, 33, 145-163. doi:10.1111/j.1467-9221.2011.00865.x.

Chaban, N., Bain, J., \& Stats, K. (2007). Under Construction: Images of the Enlarging EU in the Australasian News Media. Critical Approaches to Discourse Analysis across Disciplines, 1(2), 79-95. Retrieved January 15, 2013, from http://cadaad.net/files/journal/Chaban\%20et\%20al.\%20$\% 20$ Under\%20consturction.pdf

Cook-Sather, A. (2003). Movements of Mind: The Matrix, Metaphors, and Re-imagining Education, Teachers College Record, 105(6), 946-977 (DOI: 10.1111/1467-9620.00274) .

Drulak, P. (2004). Metaphor Europe Lives by: Language and Institutional of the European Union, EuI Working Paper SPS No.2004/15. Retrieved on January 17, 2010, from http://cadmus.eui.eu/dspace/bitstream/1814/2632/1/sps2004-15.pdf

Drulak, P. (2005). Identifying and assessing metaphors: discourse on European future. ECPR joint sessions of workshops, Granada, 14-19 April 2005. Workshop 14: "Metaphor in Political Science"_Retrieved January 17, 2010, from http://eis.bris.ac.uk/ potfc /Granada/ Papers/Drulak.pdf.

Drulák, P. \& Königová, L. (2007). Figuring Out Europe: EU Metaphors in the Minds of Czech Civil Servants, Perspectives. Review of International Affairs, 28, (5-23). Retrieved January 16, 2010, from http://www.britannica.com/ bps/additionalcontent /18/27623797/Figuring-OutEurope-EU-Metaphors-in-the-Minds-of-Czech-Civil-Servants

Durovic, T. (2009). Unity in Diversity. The conceptualisation of Language in the European Union, Facta Universitatis, Series: Linguistics and Literature, 7(1), 47-61.

European Commission, (2006). Special Eurobarometer, Attitudes towards European Union Enlargement. Fieldwork March-May 2006, Publication July 2006.

Everston, C. M., Weade, R., Green, J. L., \& Crawford, J. (1985). Effective Classroom Management and Instruction: An Exploration of Models. Final report. National Institute of Education Grant (NIE-G-83-0063).

Fernandez, J. W. (1971). Persuasions and Performances: Of the Beast in Every Bodyyand the Metaphors of Everyman, In C. GEERTZ (Ed.), Myth, symbol, and culture (39-60). New York: W. W. Norton and Company

Flash Eurobarometer (2011). Attitudes towards the EU in the United Kingdom Analytical Report. Retrived December 21, 2014 from: http://www.google.com.tr/url?sa=t\&rct=j\&q=

$\&$ esrc=s\&source $=$ web $\& \mathrm{~cd}=1 \&$ ved $=0 \mathrm{CCAQFjAA} \& u r l=\mathrm{http} \% 3 \mathrm{~A} \% 2 \mathrm{~F} \% 2 \mathrm{Fec}$.europa. eu $\% 2 \mathrm{Fpubli}$ c_opinion\%2Fflash\%2Ffl_318_en.pdf\&ei=7ciWVJ_2IYTR7QaVp4HYDg\&usg=AFQjCNGVihz PK9I1I01NWIpDefrimnM1Q\&bvm=bv.82001339, d.d2s

Gillespie, D. (2005). Misreading Charlie: Interpreting a Teaching Story through Metaphor Analysis, McGill Journal of Education, 40(1), 131-142.

Grisham, D. L. (2000). Connecting theoretical conceptions of reading to practice: A longitudinal study of elementary school teachers, Reading Psychology, 21, 145-170. 
Kimmel, M. (2009). Metaphors of the EU constitutional debate - Ways of charting discourse coherence in a complex metaphor field. Retrieved January 15, 2010, from http://www.metaphorik.de/sites/www.metaphorik.de/files/journal-pdf/17_2009_kimmel.pdf

Lakoff, G. (1993). The contemporary theory of metaphor. In A. ORTONY (Ed.), Metaphor and Thought. (202-251). Cambridge: Cambridge University Press.

Lakoff, G. (2002). The brain, the mind, and language: Why they matter in personal life, in politics, and throughout the academic world. Invited lecture, Bryn Mawr College, Bryn Mawr, PA.

Lakoff, G.,\&Johnson, M. (1980).Metaphors we live by.Chicago:University of Chicago Press.

Lakoff, G., \& Johnson, M. (1999). Philosophy in the flesh: The embodied mind and its challenge to western thought. New York: Basic Books.

Levin, T. \& Wagner, T. (2006). In Their Own Words: Understanding Student Conceptions of Writing through Their Spontaneous Metaphors in the Science Classroom, Instructional Science, 34, 227-278.

Miller, C., East, K., Fitzgerald, L., Heston, M.L., \& Veenstra, T. (2002). Visions of Self in the Act of Teaching: Using Personal Metaphors in Collaborative Study of Teaching Practices, Teaching and Learning the Journal of Natural Inquiry, 16(3), 81-93.

Munby, H. (1986). Metaphor in the thinking of teachers: An Exploratory Study, Journal of Curriculum Studies, 18(2), 197-209.

Ocak, G. and Gündüz, M. (2006). The Comparison of Pre-Service Teachers' Metaphors about the Teacher-Profession before and After the 'Introduction To Teacher-Profession' Course, Afyon Kocatepe Uni. Journal of Social Sciences, 8(2), 293-311

Ocak, G. (2011). Pre-service elementary teachers' metaphors of constructive learning. Student Attitudes (Ed. Leehu Zysberg). Hauppauge-United States of America: Nova Science Publishers, (ISBN: 978-1-61470-474-4)

O'Connor, S. \& McGowan, L. (2003). Euro Vision: Attitudes towards the European Union. Research Update, 19, 1-4.

Palmer, P. (1998). The Courage to Teach. CA: Jossey-Bass, San Francisco

Provenzo, E. F., JR., Mccloskey, G. N., Kottkamp, R. B., \& Cohn, M. M. (1989). Metaphor and Meaning in the Language of Teachers, Teachers College Record,90(4), 551-573.

Quine, W. V. O. (1963). Word and object. Cambridge: Massachusetts Institute of Technology Press.

Saban, A., Koçbeker, B.N., Saban, A. (2005). The metaphors that prospective teachers have on the concept of the Teacher, XIV. National Education Science Congress (28-30 September 2005), Pamukkale Uni. Faculty of Education. Denizli. (540)

Sabaté Dalmau, M. (2005), The Iron Lady versus La Dama de Ferro: Western Male-centred Metaphors about Europe in the British and the Catalan Public Discourse, Retrieved January 26, 2010, from: http://www.dur.ac.uk/andreas.musolff/eurofamily.pdf

Standard Eurobarometer 77. (2012). European Citizenship. Retrived from December 21,2014,from:http://www.google.com.tr/url?sa=t\&rct=j\&q=\&esrc=s\&source=web\&cd=1\&ved=0 CCAQFjAA\&url=http\%3A\%2F\%2Fec.europa.eu\%2Fpublic_opinion\%2Farchives\%2Feb\%2Feb 77\%2Feb77_citizen_en.pdf\&ei=P8iWVKmIKiu7AbBnYCQDg\&usg=AFQjCNHAq5jxGvR0I8A s0Gz5Z8cfsrFRUw\&bvm=bv.82001339,d.d2s.

Tobin, K. (1990). Changing metaphors and beliefs: A master switch for teaching? Theory into Practice, 29(2), 122-127. 


\section{Turkish Abstract}

\section{Türk Öğrencilerin Avrupa Birliği Konusundaki Metaforları}

$\mathrm{Bu}$ nitel çalışmanın amacı ilkokul öğrencilerinin Avrupa Birliği hakkında oluşturdukları metaforları incelemek ve karşılaştırmaktır 399 tane öğrenci bu çalışmaya katılmıştır. Veri toplamak için öğrencilere verilen formda öğrencilere Avrupa Birliğiyle ilgili düşüncelerini belirtmeleri istenmiştir. Toplanan veriye göre, katılımcıların ürettikleri metaforlar 8 gruba ayrılmıştır. Analizlere ve çalışmanın sonuçlarına göre, öğrenciler Avrupa Birliğini gelecek, demokrasi, özgürlük ve başarı gibi daha pozitif kavramlarla açıklamaya çalışmışlardır. Fakat, öğrenciler ayrıca son, uçurum, sömürgeci, faydacı ve boşluk gibi negatif metaforlar da üretmişlerdir.

Anahtar Kelimeler: Metafor, Avrupa Birliği, İlköğretim ikinci kademe (Ortaokul), Türk Öğrenciler

\section{French Abstract}

\section{Les Métaphores d'Étudiants Turcs de l'Union Européenne}

Le but de cette étude qualitative était d'examiner et comparer l'École primaire de métaphores des produits alimentaires d'Étudiants de Niveau Secondaires de l'Union européenne. Un total de 399 École primaire des étudiants de Niveau Secondaires a été impliqué dans cette étude. En formulaire donnée aux étudiants pour la collecte de données, on a demandé aux étudiants d'exprimer leurs avis sur l'Union européenne. Selon les données a conclu, les métaphores des participants ont été catégorisées dans 8 groupes. Selon l'analyse et les résultats de l'étude, les étudiants ont essayé d'expliquer l'UE plus avec des concepts positifs comme le développement d'avenir, la démocratie, la liberté, le succès. Cependant, ils ont produit des métaphores négatives comme l'impasse, l'abîme, le colon, la difficulté, l'utilitariste, le blanc.

Mots-clés: Métaphore, Union européenne, Écoles primaires Partie Secondaire, École Primaire, Étudiants Turcs

\section{Arabic Abstract}

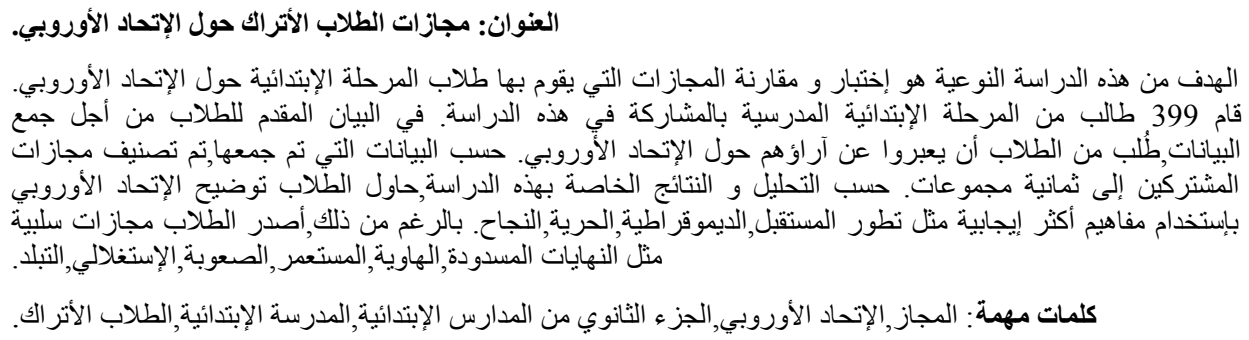

